\title{
Performance of Different Varieties with Respect to Growth, Yield and Quality of Broccoli (Brassica oleracea var. italica L.) under North Gujarat Conditions
}

\author{
T. Tejaswini" ${ }^{*}$ L.R. Varma, P. Verma, R.I. Prajapathi and F.B. Vani \\ Department of Vegetable Science, College of Horticulture, SD Agricultural University, \\ Sardarkrushinagar - 385506, Gujarat, India \\ *Corresponding author
}

\begin{tabular}{|c|c|}
\hline & A B S T R A C T \\
\hline & \multirow{6}{*}{ 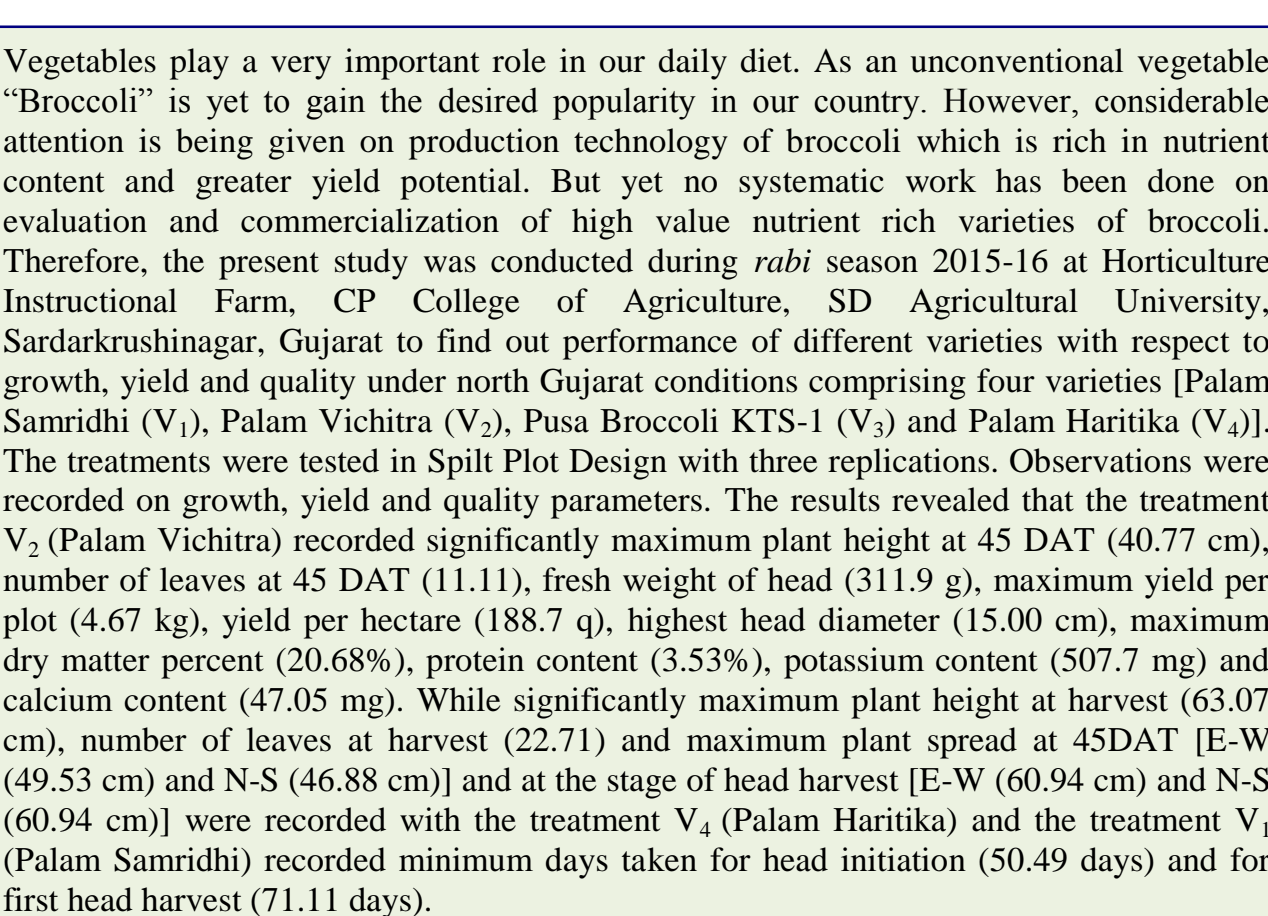 } \\
\hline & \\
\hline & \\
\hline Article & \\
\hline & \\
\hline & \\
\hline
\end{tabular}

\section{Introduction}

Broccoli (Brassica oleracea var. italica. L) is one of the most prominent vegetable grown all over the world and is an important fancy and highly nutritive exotic vegetable. It is a member of cruciferous family having many important vegetables such as Cauliflower, Cabbage, Knol-khol, Brussels sprout, Kale and Chinese cabbage. It is also known as winter broccoli or heading broccoli or Italian broccoli. It is considered to be originated from 
wild cabbage, Brassica oleracea var. oleracea (syn. Brassica oleracea var. Sylvestris L.), which is found growing wild along the Mediterranean Sea.

This vegetable, closely resembling cauliflower but usually green in color, introduced in India many years after cabbage and cauliflower and has gained popularity in short span of time. Now, India stands at second position for cauliflower and broccoli production with an annual production of 6.7 million tones. Broccoli is a rich source of sulphoraphane which is associated with reducing the risk of cancer (Guo et al., 2001). The primary inflorescence was characterized by higher levels of dry matter, total nitrogen, vitamin-C, chlorophylls, $\beta$-carotene, carotenoids and by lower levels of nitrates.

Nutritionally, it is rich in vitamin-A (2500 I.U.), vitamin-C (113 $\mathrm{mg})$, protein (3.6 g), carbohydrates $(5.9 \mathrm{~g})$ and minerals like calcium (103 mg), iron (1.1 mg), phosphorous (78 mg), potassium (382 $\mathrm{mg}$ ) and sodium (15 $\mathrm{mg}$ ) per $100 \mathrm{gm}$ of edible portion (Rana, 2008). After harvesting the head, its green leaves are also a good source of nutritious green fodder (Kumar et al., 2007).

In India, it is being used as a fresh vegetable, whereas in USA and European countries it is used as fresh as well as frozen form. It is usually boiled or steamed but may be eaten raw as salad and is liked in soups. The anticancer benefits of broccoli are greatly reduced if the vegetable is boiled. However, other preparation method such as steaming, microwaving and frying had no significant effect on the constituent compounds (Jeffery, 2005).

There are two types of broccoli, heading and sprouting. Most common broccoli is of the heading type which is closely related to cauliflower and forms a large central head.
Sprouting or Italian broccoli form many florets or small heads but they do not produce a solid head. Its edible portion consists of immature, fully-differentiated flower buds and tender portions of the upper stem.

Numbers of superior broccoli varieties are released by different universities and ICAR Institutes but there is no any recommendation has been available with respect to suitability of specific variety for certain region. So, there is a research need to make a certain recommendations to generate research evidences with respect to suitability of certain varieties in a specific season to benefit the growers of North Gujarat region.

\section{Materials and Methods}

The present experiment was carried out at Horticulture Instructional Farm, CP College of Agriculture, Sardarkrushinagar Dantiwada Agricultural University, Sardarkrushinagar, Gujarat during rabi season 2015-16. The soil of the experimental plot was well drained with good water holding capacity. As per recommendation for this zone 20 tonnes of farm yard manure (FYM), $50 \mathrm{~kg} \mathrm{~N}, 50 \mathrm{~kg} \mathrm{P}$ and $50 \mathrm{~kg} \mathrm{~K}$ in the form of urea, single super phosphate and murate of potash were applied at the time of soil preparation. The remaining half dose $50 \mathrm{~kg}(50 \%)$ of nitrogen was applied as top dressing in two splits at 20 and 30 days after transplanting.

The experiment was laid out in a split plot design with three replications. The experimental area was divided into plots of $2.70 \mathrm{~m} \times 1.80 \mathrm{~m}$ size. The experiment was carried out with four varieties [Palam Samridhi $\left(\mathrm{V}_{1}\right)$, Palam Vichitra $\left(\mathrm{V}_{2}\right)$, Pusa Broccoli KTS-1 $\left(\mathrm{V}_{3}\right)$ and Palam Haritika $\left(\mathrm{V}_{4}\right)$ ]. To raise the crop recommended package of practices was followed. The date of seed sowing in nursery bed was on $23^{\text {rd }}$ November 2015 and date of transplanting on $17^{\text {th }}$ 
December 2015 during Rabi season. The performance of different varieties of broccoli was studied and data recorded on germination, plant height (at transplanting, 45 days after transplanting, at harvest), number of leaves (45 days after transplanting, at harvest), plant spread (45 days after transplanting, at harvest), days taken for head initiation, days taken for harvesting, yield and quality parameters. The mean data were subjected to statistical analysis following analysis of variance technique (Panse and Sukhatme, 1985).

\section{Results and Discussion}

\section{Growth parameters}

\section{Days taken for germination}

The performance of different varieties with respect to number of days taken for germination was found significant and the data is furnished in table 1 . The significantly minimum days taken for germination (3.0) was found with treatment $\mathrm{V}_{3}$ (Pusa broccoli KTS-1) and $\mathrm{V}_{4}$ (Palam Haritika). The treatment $V_{3}$ and $V_{4}$ was found statistically at par with treatment $\mathrm{V}_{1}$ (Palam Samridhi). The maximum days taken for germination (6.0) was observed with treatment $\mathrm{V}_{2}$ (Palam Vichitra).The variation on days taken for germination may be due to genetic makeup of individual variety. These results are in accordance with the findings of Singh (2000) in cluster bean, Thakor (2008) in vegetable pea and Gogoi et al., (2016) in broccoli.

Plant height at the time of transplanting, at 45 days after transplanting and at harvest (cm)

The four different varieties of broccoli were varied significantly as shown in the table 1 . The height of the plants varied from $(19.55 \mathrm{~cm}$ - $22.07 \mathrm{~cm})$. The significantly maximum height of seedling $(22.07 \mathrm{~cm})$ was observed with the treatment $\mathrm{V}_{3}$ (Pusa broccoli KTS-1). The treatment $\mathrm{V}_{3}$ was found statistically at par with treatment $\mathrm{V}_{1}$ (Palam Samridhi) (21.95 $\mathrm{cm})$. The minimum height of seedling (19.55 $\mathrm{cm})$ at time of transplanting was recorded with treatment $\mathrm{V}_{4}$ (Palam Haritika). The significantly maximum plant height (40.77 $\mathrm{cm})$ at 45 DAT was obtained with the treatment $\mathrm{V}_{2}$ (Palam Vichitra). The minimum plant height $(32.12 \mathrm{~cm})$ was recorded with treatment $\mathrm{V}_{3}$ (Pusa broccoli KTS-1). The highest plant height observed in some varieties might be due to its inherent genotypic characteristics or for the variations in agroclimatic conditions. These findings are in close conformity with that of Chaudari et al., (2015) in Knol-khol, Hafiz et al., (2015) and Islam et al., (2015) in broccoli.

From the data it revealed that the significantly maximum plant height $(63.07 \mathrm{~cm})$ at harvest was recorded with treatment $\mathrm{V}_{4}$ (Palam Haritika) and the minimum plant height (49.37 $\mathrm{cm}$ ) was observed with treatment $\mathrm{V}_{3}$ (Pusa broccoli KTS-1). The variation in different varieties with respect to plant height might be due to their genetic makeup and also maximum number of days taken for head harvest in variety Palam Haritika. These findings are in accordance with the findings of Nooprom et al., (2013), El-Bassiony et al., (2014), Singh et al., (2014), Hafiz et al., (2015) and Thakur et al., (2016) in broccoli.

\section{Number of leaves at 45 DAT and at harvest}

The number of leaves per plant is an important character that might influence the yield. The varieties included in the study produced an average variation of $(10.16-11.11)$ leaves per plant at 45 DAT and (18.63 - 22.71) leaves per plant at harvest. The performance of different varieties with respect to number of leaves per plant at 45 DAT was found to be not significant but at harvest it was found significant and was shown in the table 2. 
Table.1 Performance of different varieties with respect to days taken for germination, plant height at the time of transplanting, 45DAT and harvesting

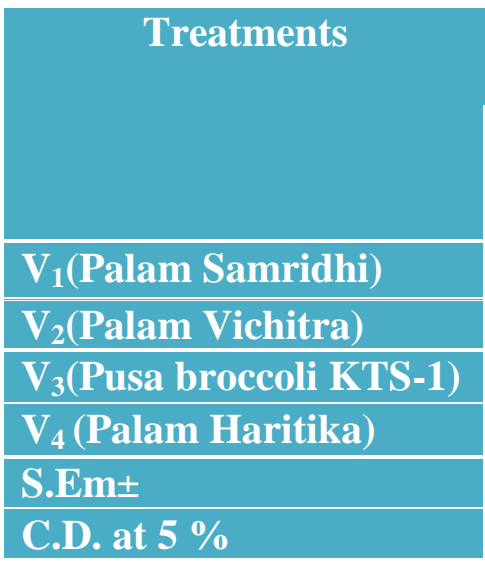

\begin{tabular}{|c|c|c|c|}
\hline \multirow{2}{*}{$\begin{array}{c}\text { Days taken } \\
\text { for } \\
\text { germination }\end{array}$} & \multicolumn{3}{|c|}{ Plant height at (cm) } \\
\cline { 2 - 4 } & Transplanting & 45DAT & Harvesting \\
\hline 3.11 & 21.95 & 34.60 & 53.49 \\
\hline 6.00 & 21.06 & 40.77 & 53.98 \\
\hline 3.00 & 22.07 & 32.12 & 49.37 \\
\hline 3.00 & 19.55 & 36.92 & 63.07 \\
\hline 0.05 & 0.32 & 0.69 & 1.11 \\
\hline 0.16 & 0.94 & 2.04 & 3.30 \\
\hline
\end{tabular}

Table.2 Performance of different varieties with respect to number of leaves per plant at 45DAT and harvesting, plant spread at 45DAT and harvesting

\begin{tabular}{|c|c|c|c|c|c|c|}
\hline \multirow[t]{3}{*}{ Treatments } & \multicolumn{2}{|c|}{$\begin{array}{c}\text { Number of leaves per } \\
\text { plant }\end{array}$} & \multicolumn{4}{|c|}{ Plant spread(cm) } \\
\hline & \multirow[t]{2}{*}{ 45DAT } & \multirow[t]{2}{*}{ Harvesting } & \multicolumn{2}{|c|}{ 45DAT } & \multicolumn{2}{|c|}{ Harvesting } \\
\hline & & & $(\mathbf{E}-\mathbf{W})$ & $(\mathbf{N}-\mathrm{S})$ & $(\mathrm{E}-\mathrm{W})$ & $(\mathrm{N}-\mathrm{S})$ \\
\hline V1(Palam Samridhi) & 10.56 & 18.68 & 44.08 & 43.73 & 55.91 & 57.00 \\
\hline V $_{2}$ (Palam Vichitra) & 11.11 & 21.47 & 45.90 & 46.08 & 59.75 & 59.32 \\
\hline $\mathrm{V}_{\mathbf{3}}$ (Pusa broccoli KTS-1) & 10.58 & 18.63 & 43.69 & 42.21 & 59.58 & 55.43 \\
\hline V $_{4}($ Palam Haritika $)$ & 10.16 & 22.71 & 49.53 & 46.88 & 60.94 & 60.94 \\
\hline S.Em & 0.278 & 0.438 & 0.725 & 1.200 & 0.809 & 1.229 \\
\hline C.D. at $5 \%$ & NS & 1.301 & 2.154 & 3.564 & 2.405 & 3.650 \\
\hline
\end{tabular}

Table.3 Performance of different varieties with respect to days taken for head initiation, days taken for head harvesting, head diameter, yield per plant (gm), yield per plot $(\mathrm{kg})$ and yield per hectare $(\mathrm{q})$

\begin{tabular}{|c|c|c|c|c|c|c|}
\hline Treatments & $\begin{array}{c}\text { Days } \\
\text { taken for } \\
\begin{array}{c}\text { head } \\
\text { initiation }\end{array}\end{array}$ & $\begin{array}{l}\text { Days taken } \\
\text { for head } \\
\text { harvesting }\end{array}$ & $\begin{array}{c}\begin{array}{c}\text { Head } \\
\text { diameter }\end{array} \\
(\mathrm{cm})\end{array}$ & $\begin{array}{l}\text { Yield } \\
\text { per } \\
\text { plant } \\
\text { (gm) }\end{array}$ & $\begin{array}{c}\text { Yield } \\
\text { per } \\
\text { plot } \\
\text { (kg) }\end{array}$ & $\begin{array}{c}\begin{array}{c}\text { Yield per } \\
\text { hectare }\end{array} \\
(q)\end{array}$ \\
\hline V $_{1}$ (Palam Samridhi) & 50.49 & 71.11 & 13.6 & 280.3 & 4.24 & 178.9 \\
\hline $\mathbf{V}_{2}$ (Palam Vichitra) & 70.67 & 90.67 & 15.0 & 311.9 & 4.67 & 188.7 \\
\hline $\mathrm{V}_{3}$ (Pusa broccoli KTS-1) & 54.91 & 75.20 & 13.0 & 251.6 & 4.00 & 157.3 \\
\hline $\mathrm{V}_{4}$ (Palam Haritika) & 85.20 & 103.67 & 10.2 & 133.0 & 0.83 & 85.6 \\
\hline S.Em \pm & 0.46 & 0.62 & 0.43 & 11.86 & 0.11 & 8.16 \\
\hline C.D. at $5 \%$ & 1.37 & 1.84 & 1.28 & 35.24 & 0.33 & 24.25 \\
\hline
\end{tabular}


Table.4 Performance of different varieties with respect to quality parameters

\begin{tabular}{|c|c|c|c|c|}
\hline Treatments & $\begin{array}{c}\text { Total dry matter content } \\
\text { of the head }(\%)\end{array}$ & $\begin{array}{c}\text { Crude } \\
\text { protein }(\%)\end{array}$ & $\begin{array}{l}\text { Potassium } \\
\text { (mg/100gm) }\end{array}$ & $\begin{array}{l}\text { Magnesium } \\
\text { (mg/100gm) }\end{array}$ \\
\hline V $_{1}$ (Palam Samridhi) & 19.37 & 2.80 & 455.5 & 45.61 \\
\hline $\mathrm{V}_{2}$ (Palam Vichitra) & 20.68 & 3.53 & 507.7 & 47.05 \\
\hline $\mathbf{V}_{3}$ (Pusa broccoli KTS-1) & 18.54 & 2.60 & 444.4 & 40.71 \\
\hline $\mathrm{V}_{4}$ (Palam Haritika) & 20.46 & 2.62 & 437.7 & 36.75 \\
\hline S.Em \pm & 0.088 & 0.04 & 3.993 & 0.44 \\
\hline C.D. at $5 \%$ & 0.26 & 0.11 & 11.86 & 1.32 \\
\hline
\end{tabular}
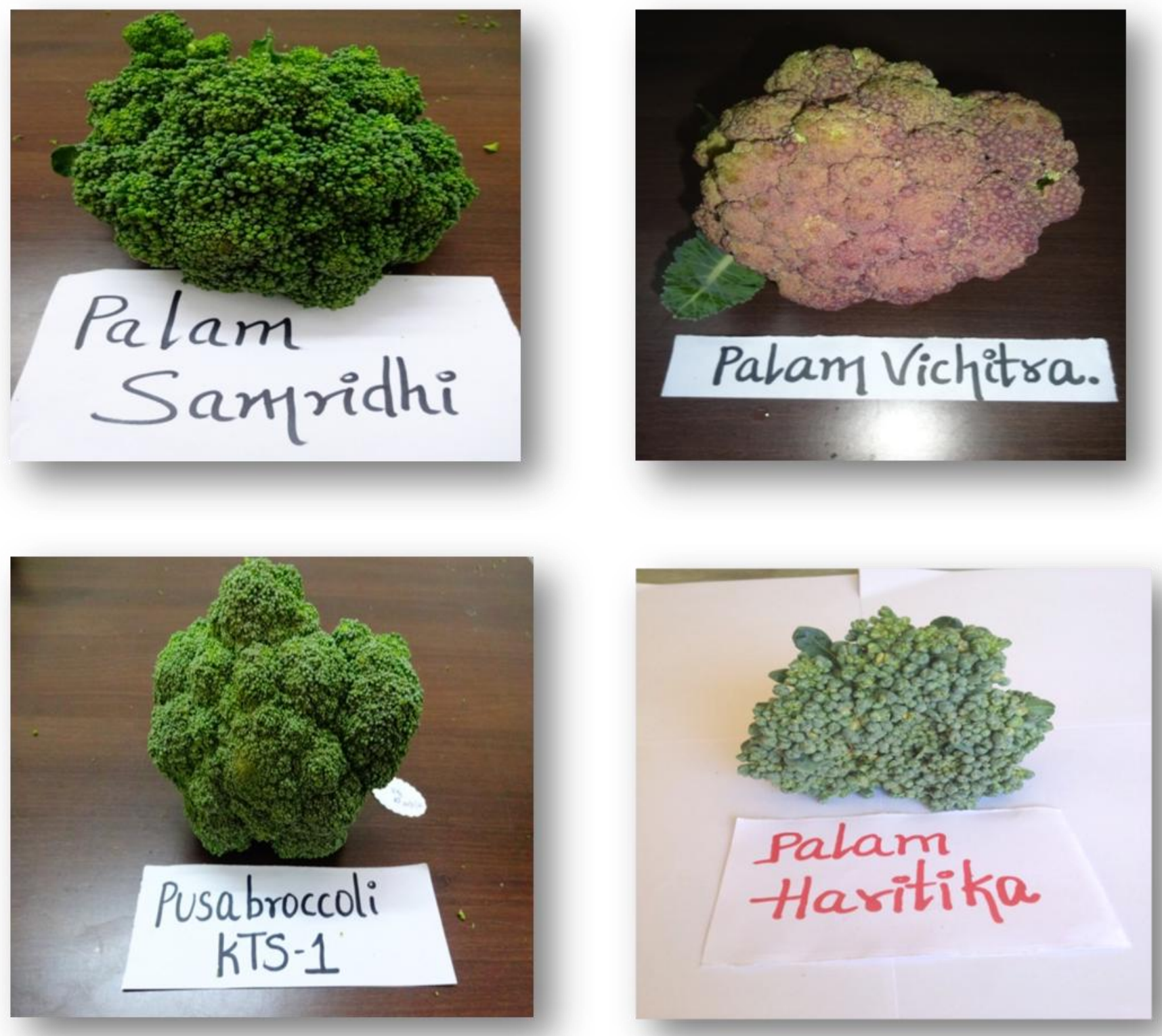
The significantly maximum number of leaves (22.71) per plant at was observed with treatment $\mathrm{V}_{4}$ (Palam Haritika) and the minimum number of leaves at harvest (18.63) was observed with treatment $\mathrm{V}_{3}$ (Pusa broccoli KTS-1). In this investigation variation in number of leaves per plant under different varieties, might be due to differences in their genetic inherent capacity, and suitability under this climate. The lower number of leaves in some cultivars was probably due to slow rate in leaf initiation. These findings are in close accordance with the findings of El- Magd et al., (2006), ElMagd et al., (2013), Thapa and Rai (2012) in broccoli.

\section{Plant spread (E-W and N-S) at 45 DAT} and at harvest

In this present investigation, plant spread in each variety were recorded and found significant difference as shown in table 2 . The significantly maximum plant spread at 45 DAT [E-W $(49.55 \mathrm{~cm})$ and $\mathrm{N}-\mathrm{S}(46.86 \mathrm{~cm})]$ and at harvest $[\mathrm{E}-\mathrm{W}(60.94 \mathrm{~cm})$ and $\mathrm{N}-\mathrm{S}$ $(60.94 \mathrm{~cm})]$ was recorded with treatment $\mathrm{V}_{4}$ (Palam Haritika). The treatment $\mathrm{V}_{4}$ was found statistically at par with treatment $\mathrm{V}_{2}$ (Palam Vichitra) and the minimum plant spread was recorded with treatment $\mathrm{V}_{3}$ (Pusa broccoli KTS-1) at 45 DAT and $V_{1}$ (Palam Samridhi) at harvest. The variation in different varieties with respect to plant spread [E-W and N-S] may be due to their inherent genetic makeup, number of days taken for head harvesting and suitability under this climate. These findings are in accordance with the findings of ElBassiony et al., (2014), Singh et al., (2014), Hafiz et al., (2015) and Thakur et al., (2016) in broccoli

\section{Days taken for head initiation}

From the data as shown in table 3 it revealed that the significantly minimum days taken for head initiation (50.49 days) was recorded with treatment $\mathrm{V}_{1} \quad$ (Palam Samridhi). The maximum days taken for head initiation (85.20 days) was observed in treatment $\mathrm{V}_{4}$ (Palam Haritika). This similarity and dissimilarity among the varieties in number of days taken for head initiation may be attributed to the variability in their genetic configuration and variability with respect to suitability of the climate of the particular region. These results are in corroborate with findings of Dev (2012), Thapa and Rai (2012), Nooprom and Santiprachi (2013), Gogoi et al., (2016), and Thakur et al., (2016) in broccoli.

\section{Days taken for first head harvesting}

The performance of different varieties on days taken for first head harvest was found significant and data was shown in table 3. The significantly minimum days taken for first head harvest (71.11 days) was recorded with treatment $\mathrm{V}_{1}$ (Palam Samridhi). The treatment $\mathrm{V}_{1}$ was found statistically at par with treatment $\mathrm{V}_{3}$ (Pusa broccoli KTS-1) (75.20 days). The maximum days taken for first head harvest (103.67 days) was observed with treatment $\mathrm{V}_{4}$ (Palam Haritika). The earliness in edible maturity might be due to genetical difference among the different varieties. These results are collaborating with the findings of Thapa and Rai (2012), Nooprom and Santiprachi (2013), Gogoi et al., (2016), and Thakur et al., (2016) in broccoli.

\section{Head diameter}

The performance of different varieties with respect to head diameter was found to be significant (Table 3). The significantly maximum head diameter $(15.00 \mathrm{~cm})$ was obtained with treatment $\mathrm{V}_{2}$ (Palam Vichitra). The treatment $V_{2}$ was found statistically at par with treatment $\mathrm{V}_{1}$ (Palam Samridhi) (13.6 $\mathrm{cm})$. The minimum head diameter $(10.2 \mathrm{~cm})$ was obtained with treatment $\mathrm{V}_{4}$ (Palam Haritika). The difference in diameter of head 
might be due to genetic makeup of different varieties and adaptability to soil and climatic condition of this region. These finding in accordance with the finding of Sharma et al., (2005) in Brussels sprout, Kumar et al., (2007) in broccoli, Bhangre et al., (2011) in broccoli, Uddain et al., (2012) in knol-khol, Kumar et al., (2012) in cabbage, Yadav et al., (2013) in cauliflower and Giri et al., (2013) in broccoli.

\section{Yield parameters}

Yield and yield attributing characters of different varieties (Table 3) showed significant differences. The highest fresh weight of head $(311.9 \mathrm{~g})$, maximum head yield per plot (4.67 $\mathrm{kg})$, head yield per hectare $(188.75 \mathrm{q})$ was found with treatment $\mathrm{V}_{2}$ (Palam Vichitra). The treatment $V_{2}$ (Palam Vichitra) was found statistically at par with the treatment $\mathrm{V}_{1}$ (Palam Samridhi) and the minimum fresh weight of head $(133.0 \mathrm{~g})$, head yield per plot $(0.83 \mathrm{~kg})$, head yield per hectare (85.59 q) was obtained with treatment $\mathrm{V}_{4}$ (Palam Haritika). These significant differences with respect to fresh weight of head, head yield per plot and head yield per hectare among different varieties may be due to their own-genetic makeup and the suitability of varieties to the weather conditions of this zone. These findings are in conformity with the results, El-Bassiony et al., (2014) in knol-khol, Bhangre et al., (2011) in broccoli, Moniruzzaman (2011) in cabbage, Thapa and Rai (2012) of broccoli, Uddain et al., (2012) in knol-khol, Thapa et al., (2013), Chandan et al., (2013) in broccoli, El-Magd (2013), Giri et al., (2013), Nooprom et al.,(2013), Nguille et al., (2014), Singh et al., (2014) and Islam et al., (2015) and Thakur et al., (2016) in Broccoli.

\section{Quality parameters}

The quality parameter were also analysed and were shown in table 4 such as total dry matter content of the head, crude protein content, potassium content and calcium content was found significant. Significantly maximum total dry matter content of head $(20.68 \%)$, highest protein content $(3.53 \%)$, maximum potassium content $(507.7 \mathrm{mg})$ and calcium content (47.05 $\mathrm{mg}$ ) was obtained with treatment $\mathrm{V}_{2}$ (Palam Vichitra).The minimum dry matter content $(18.54 \%)$, crude protein content $(2.60 \%)$ was observed with treatment $\mathrm{V}_{3}$ (Pusa broccoli KTS1) whereas the minimum potassium and calcium content was observed with treatment $\mathrm{V}_{4}$. The variation in dry matter content of the head, crude protein content, potassium and calcium content of different varieties may be due to inherent characters of different genotype and their genetic setup. This showed that the cultivars represent a good range of genetic diversity in response of quality parameters. These findings are in accordance with the findings of Kalloo et al., (2005) in vegetable pea, Bhangre et al., (2011) in broccoli, Uddain et al., (2012) in knol-khol, Chandan et al., (2013) in broccoli, El-Magd et al., (2013), Amin et al., (2014) in cowpea, Islam et al., (2015) in broccoli and Patel (2015) in cowpea.

The present study revealed that the growth, yield and quality attributing characters significantly differed within the different varieties. On the basis of performance of different varieties on growth attributes like plant height, number of leaves per plant at 45DAT, yield parameters like fresh weight of head $(311.9 \mathrm{~g})$, head yield per plot $(4.67 \mathrm{~kg})$, head yield per hectare (188.75 q) quality parameters like total dry matter content of head $(20.68 \%)$, crude protein content $(3.53 \%)$, potassium content $(507.7 \mathrm{mg})$ and calcium content $(47.05$ $\mathrm{mg}$ ) was obtained with treatment $\mathrm{V}_{2}$ (Palam Vichitra).

\section{References}

Amin, A.U., Agalodia, A.V. and Prajapati, D.B. (2014). Performance of cowpea varieties on growth, yield and quality parameters. State Seed Committee Report CRSS, Jagudan.

Bhangre, K.K., Sonawane, P. C and Warade, S. D. (2011). Effect of different varieties and spacing on growth and yield parameters of broccoli (Brassica oleracea var italica) under Pune conditions, Asian Journal of 
Horticulture. 6(1): 74-76.

Chandan, K., Raturi, H. C. and Uniyal, S.P. (2013). Performance of cabbage hybrids under rainfed mid-hill conditions of Uttarakhand. The Asian Journal of Horticulture. 8(1): 110-113.

Chaudari, A. H., Vadodaria, J. R., Patel, H. T. and Patel, G. S. (2015). Performance of different varieties and planting data on growth of Khol-knol (Brassica oleracea var. gongylodes). IMPACT: International Journal of Research in Applied, Natural and Social Sciences. 3(8): 39-42.

Dev, H. (2012) Standardization of planting time and spacing in broccoli cv Green Head for lower hills of northern India. International Journal of Farm Science. 2: 36-42.

El-Bassiony, A. M., Fawzy, Z. F., El-Nemr, M. A. and Yunsheng, L. (2014). Improvement of growth, yield and quality of two varieties of khol-rabi plants as affected by application of some biostimulants. Middle East Journal of Agriculture Research. 3(3): 491-498.

El-Magd, M. M. (2013). Evaluation of some broccoli cultivars on growth, head yield and quality under different planting dates. Journal of Applied Sciences Research. 9(11): 5730-5736.

El-Magd, M. M. A., El-Bassiony, A.M. and Fawzy, Z.F. (2006). Effect of organic manure with or without chemical fertilizers on growth, yield and quality of some varieties of broccoli plants. Journal of Applied Science Research. 2(10): 791798.

Giri, R. K., Sharma, M. D., Shakya, S. M., GC, Y. D. and Kandel, T.P. (2013). Growth and yield response of broccoli cultivars to different rates of nitrogen in western chitwan, Nepal. Agriculture Science. 4 (7A): 8-12.

Gogoi, S., Millu, R., Das, P., Bora, N. and Das, B. K. (2016). Effect of sowing dates and spacing on broccoli (Brassica oleracea var. italica) seed production. Indian Journal of Agricultural Research. 50(4): 350-353.
Guo, J. H., Lee, S., Chiang, F. and Chang, C. (2001). Antioxidant properties of the extracts from different parts of broccoli in Taiwan. Journal of food and Dry Analysis. 9: 96-101.

Hafiz, M. A., Biswas, A., Zakaria, M., Hassan, J. and Ivy, N.A. (2015). Effect of planting dates on the yield of broccoli genotypes. Bangladesh Journal of Agriculture Research. 40(3): 465-478.

Jeffery, 2005. Maximizing the anti-cancer power of broccoli. Science daily, 5th, April, 2005. www.sciencedaily.com/ releases/2005/03/050326114810.htm.

Kalloo, G., Rai, M., Singh, J., Varma, A., Kumar, R., Rai, G.K. and Vishwanath (2005). Morphological and biological variability in vegetable pea (Pisum sativum L.). Vegetable Science, 32 (1): 19-23

Kumar, N., Praskash, V. and Srivastva, A.K. (2007). Effect of transplanting dates and geometries on broccoli (Brassica oleracea var. italica) under mid hill conditions of North- West Himalaya. Indian Journal of Agricultural sciences. 77 (7): 448-450.

Kumar, R., Singh, R.P. and Pal, Y. (2012). Yield and Quality of Brassica species as influenced by different dates of sowing and varieties. Pantnagar Journal of Research. 6(1): 112-115.

Moniruzzaman. M. (2011). Effect of plant spacings on the performance of hybrid cabbage (Brassica oleracea var. capitata) varieties. Bangladesh Journal of Agriculture Research. 36(3): 495-506.

Ngullie, R. and Biswas, P.K. (2014). Performance of different varieties of broccoli under rainfed mid-hill conditions of Mokokchung district of Nagaland. International Journal of Farm Science. 4(2): 76-79.

Nooprom, K. and Santiprachi, Q. (2013). Effects of planting dates and varieties on growth and yield of broccoli during rainy season. American Journal of Agricultural and Biological Sciences. 8(4): 37-361.

Panse, V. G. and Sukhatme, P. V. 
(1985).Statistical methods for agricultural workers, ICAR. Pub., New Delhi.

Patel, D.M. (2015). Varietal evaluation of vegetable cowpea (Vigna unguiculata L.) Walp.]. under North Gujarat condition. Unpublished M.Sc. (Veg.) Thesis submitted to S. D. Agricultural University, Sardarkrushinagar.

Sharma, A., Sonia, S., Sharma, J.J. and Kumar, R. (2005). Effect of Planting date, plant density and fertilizer levels on sprouts yield and yield attributing characters of brussels sprout (Brassica oleracea var. gemmifera) under high hill dry temperate conditions of north- west Himalayas. Indian Journal of Agricultural Science. 75 (5): 292-293.

Sharma, S. (1998). Varietal response of cabbage (Brassica oleracea var. capitata L.) to planting dates and plant population during summer season. M.sc (thesis), Himachal Pradesh, KVK, Palampur.

Singh, J. (2000). Response of cluster bean [Cyamopsis tetragonoloba (L.)Taub.] Varieties of different spacing during summer season. Unpublished M.Sc. (Agri.) Thesis, Gujarat Agricultural University, Sardarkrushinagar.

Singh, R., Chaursasia, S. N. S and Singh, S. N. (2006). Response of nutrient sources and spacing on growth and yield of broccoli (Brassica oleracea var. italica). Vegetable science. 33: 198-200.

Singh, R., Kumar, S. and Sanjay Kumar.
(2014). Performance and preference of broccoli varieties grown under low-hill conditions of Himachal Pradesh. Indian Research Journal. 14(1): 112-114.

Thakor, D.P. (2008). Influences of different cultivars and plant spacing on growth, yield and quality of garden pea. Unpublished M.Sc. (Agri.) Thesis, submitted to Sardarkrushinagar Dantiwada Agricultural University, Sardarkrushinagar.

Thakur, S., Thakur, R. and Mehtha, D. K. (2016). Evaluation of different genotypes of broccoli in dry temperate conditions of Kinnur district of Himachal Pradesh in India. International Journal of science, Environment and Technology. 5(3): 16731679.

Thapa, U. and Rai, R. (2012). Evaluation of sprouting broccoli (Brassica oleracea var. italica). Genotypes for growth, yield and quality. International Journal of Agriculture sciences. 4 (7): 284-286.

Uddain, J., Liton, M. M. U. A. and Rahman, M. S. (2012). Organic farming practices on different kohl-rabi (Brassica oleracea var. gongylodes L.) cultivars. International Journal of Bio-resource and stress management. 3(3).

Yadav, M., Prasad, V. M. and Ahirwar, C.S. (2013). Varietal evolution of cauliflower (Brassica oleracea var. botrytis L.) in Allahabad agro-climate condition. Trends in biological science. 6(1): 99-100.

\section{How to cite this article:}

Tejaswini, T., L.R. Varma, P. Verma, R.I. Prajapathi and Vani, F.B. 2018. Performance of Different Varieties with Respect to Growth, Yield and Quality of Broccoli (Brassica oleracea var. italica L.) under North Gujarat Conditions. Int.J.Curr.Microbiol.App.Sci. 7(06): 690-698. doi: https://doi.org/10.20546/ijcmas.2018.706.081 